\title{
Fusarium Species in Mangrove Soil in Northern Peninsular Malaysia and the Soil Physico-Chemical Properties
}

\author{
Wafa S. Mohamed Zubi, Masratul Hawa Mohd, Nik Mohd Izham Mohamed Nor and Latiffah Zakaria *
}

check for

updates

Citation: Mohamed Zubi, W.S.; Mohd, M.H.; Mohamed Nor, N.M.I.; Zakaria, L. Fusarium Species in Mangrove Soil in Northern Peninsular Malaysia and the Soil Physico-Chemical Properties. Microorganisms 2021, 9, 497. https://doi.org/10.3390/ microorganisms 9030497

Academic Editor: Gary A. Strobel

Received: 30 December 2020

Accepted: 12 February 2021

Published: 26 February 2021

Publisher's Note: MDPI stays neutral with regard to jurisdictional claims in published maps and institutional affiliations.

Copyright: (c) 2021 by the authors. Licensee MDPI, Basel, Switzerland. This article is an open access article distributed under the terms and conditions of the Creative Commons Attribution (CC BY) license (https:// creativecommons.org/licenses/by/ $4.0 /)$.
School of Biological Sciences, Universiti Sains Malaysia, Penang 11800, USM, Malaysia; wwwafaaa@yahoo.com (W.S.M.Z.); masratulhawa@usm.my (M.H.M.); nikizham@usm.my (N.M.I.M.N.)

* Correspondence: Lfah@usm.my; Tel.: +604-6533506

\begin{abstract}
Fusarium genus comprises important saprophytic and phytopathogenic fungi and is widespread in nature. The present study reports the occurrence of Fusarium spp. in soils from two mangrove forests in northern Peninsular Malaysia and analyzed physico-chemical properties of the mangrove soil. Based on TEF- $1 \alpha$ sequences, nine Fusarium species were identified: Fusarium solani species complex (FSSC) $(n=77)$, Fusarium verticillioides $(n=20)$, Fusarium incarnatum $(n=10)$, Fusarium proliferatum $(n=7)$, Fusarium lateritium $(n=4)$, Fusarium oxysporum $(n=3)$, Fusarium rigidiuscula $(n=2)$, Fusarium chlamydosporum $(n=1)$, and Fusarium camptoceras $(n=1)$; FSSC isolates were the most prevalent. Phylogenetic analysis of the combined TEF- $1 \alpha$ and ITS sequences revealed diverse phylogenetic affinities among the FSSC isolates and potentially new phylogenetic clades of FSSC. Soil analysis showed varied carbon content, $\mathrm{pH}$, soil moisture, and salinity, but not nitrogen content, between sampling locations. Regardless of the physico-chemical properties, various Fusarium species were recovered from the mangrove soils. These were likely saprophytes; however, some were wellknown plant pathogens and opportunistic human pathogens. Thus, mangrove soils might serve as inoculum sources for plant and human pathogenic Fusarium species. The present study demonstrates the occurrence of various Fusarium species in the extreme environment of mangrove soil, thereby contributing to the knowledge on species diversity in Fusarium.
\end{abstract}

Keywords: Fusarium species; FSSC; mangrove soil; phylogenetic; soil analysis; TEF-1 $\alpha$

\section{Introduction}

The genus Fusarium is a large taxonomically complex genus comprising more than 200 species [1]. Most Fusarium species are species complexes that appear morphologically similar but are genetically closely related and form species complexes, such as the Fusarium solani species complex (FSSC) and the Fusarium fujikuroi species complex (FFSC). Many species within the species complex are cosmopolitan, distributed in the tropics and temperate regions, and are important plant pathogens as well as opportunistic human pathogens.

As a plant pathogen, Fusarium caused various types of diseases including wilt, stem rot, fruit rot, root rot, blight, and cankers in diverse crops such as industrial crops, fruit crops, legumes, ornamentals, and cereal crops. The ability of Fusarium to infect various crops is associated with the capability of the fungus to occupy a wide range of substrates, various modes of survival and their cosmopolitan occurrence in agricultural and natural ecosystems [2].

A number of plant pathogenic Fusarium spp. produced mycotoxins in the field or during storage. Among well-known mycotoxins produced by mycotoxigenic Fusarium are fumonisins, zearalenones, trichothecenes, deoxynivalenol, and moniliformin. These mycotoxins contaminated food and feed which in turn can cause harmful effects on humans and animals. Therefore, plant pathogenic and mycotoxigenic Fusarium spp. have the ability to reduce crop yield as well as reduce the quality of agricultural products. In terms of 
global significance, Fusarium has serious implications on socio-economic and international agriculture trade [3].

One of the important soil inhabitants is Fusarium, comprising both pathogenic and nonpathogenic strains associated with plants, animals, and humans. Many Fusarium species are soil-borne pathogens and facultative parasites. As soil-borne pathogens, Fusarium species have been reported in several agricultural or cultivated soils, and the presence of Fusarium is commonly associated with plant debris and plant roots. Fusarium species have also been isolated from non-agricultural soils, such as peat soil [4], arid environment [5], and Arctic soil [6] which are considered extreme environments.

Microflora in mangrove soils comprises a combination of terrestrial, marine, and freshwater microorganisms [7]. The mangrove soil microbial community plays a major role in nutrient transformation, from residual dead mangrove plants to nitrogen, phosphorus, and other nutrients. Manglicolous fungi are mangrove fungi that are important in nutrient cycling in mangrove soil habitats $[8,9]$ as they facilitate the decomposition of mangrove materials [10].

In Malaysia, although studies on fungal communities in mangrove ecosystems have been conducted, they focused on marine fungi and phylloplane fungi [11,12]. Studies on soil microfungi in mangrove ecosystems are still lacking, even though these types of fungi are vital as decomposers for ecological function. Fusarium is an important fungal genus that causes diseases in plants, animals, and humans; however, the occurrence of Fusarium species in mangrove soil is largely unexplored. A preliminary study on Fusarium species from mangrove soil by Latiffah et al. [13], reported three Fusarium spp. In this study, mangrove soil samples were collected from one location, and the three species were identified based solely on morphological characteristics. Thus, it confirmed that mangrove soils harbor Fusarium species, and more species might be present. Fusarium species residing in mangrove soil are likely saprophytic, as well pathogenic, as many species are facultative parasites. Therefore, mangrove soil could be a reservoir for pathogenic species.

Considering its saprophytic and pathogenic role in plants, animals, and humans, the present study aimed to explore the Fusarium species in mangrove soil based on molecular identification and phylogenetic analysis, so as to accurately identify isolates of Fusarium at the species level. Additionally, several properties of the mangrove soil were also analyzed.

\section{Materials and Methods}

\subsection{Isolation and Morphological Identification of Fusarium Isolates}

Soil samples were collected from mangrove areas in the northern states of Penang and Kedah, Peninsular Malaysia (Table S1). Samples were collected at a depth of 5.0-15.0 cm from the surface, placed in polythene bags, and transported to the lab for processing. The soil samples were air-dried for $72 \mathrm{~h}$ or until fully dried. Approximately $500 \mathrm{~g}$ of the soil sample was ground using a mortar and pestle, sieved through a $2 \mathrm{~mm}$ strainer, and set aside for later use.

Three isolation methods, namely direct isolation, soil dilution, and debris isolation, as recommended by Leslie and Summerell (2006) [14], were used to isolate Fusarium from the mangrove soil samples. The medium used for isolation was peptonepentachloronitrobenzene-based agar [14].

All isolates successfully isolated from mangrove soils were tentatively identified based on their morphological characteristics as described in The Fusarium Laboratory Manual [14].

\subsection{Molecular Identification and Phylogenetic Analysis}

The translation elongation factor- $1 \alpha$ (TEF-1 $\alpha$ ) gene was used to confirm the identity of the morphologically identified Fusarium isolates as the gene is recommended for identification of Fusarium species. In addition, the internal transcribed spacer (ITS) region and $\beta$-tubulin were included in the phylogenetic analysis depending on the species identified based on the TEF-1 $\alpha$ gene [14]. ITS region and $\beta$-tubulin gene were used for phylogenetic 
analysis of F. solani isolates. For the other Fusarium spp., TEF-1 $\alpha$ and $\beta$-tubulin genes were used to perform phylogenetic analysis.

\subsubsection{DNA Extraction}

Fungal isolates were cultured in $50 \mathrm{~mL}$ potato dextrose broth and incubated for 7 days at $27 \pm 2{ }^{\circ} \mathrm{C}$. The mycelium was harvested, dried on a double-layered sterile filter paper, and kept in a freezer overnight. Then, it was lyophilized at $-40{ }^{\circ} \mathrm{C}$ for $48 \mathrm{~h}$ using a freeze dryer (Triad ${ }^{\mathrm{TM}}$ Freeze Dry, Labconco, MO, USA). The dried mycelia were ground with liquid nitrogen to a fine powder using a sterile mortar and pestle. DNA was extracted from 0.24 to $0.26 \mathrm{~g}$ of the mycelia fine powder using the DNeasy Plant Mini Kit (Qiagen, Hilden, Germany) according to the manufacturer's protocols.

\subsubsection{PCR Amplification}

PCR amplification was carried out in a DNA Engine ${ }^{\mathrm{TM}}$ Peltier Thermal Cycler Model PTC-100 (MJ Research Inc., Watertown, MA, USA). TEF-1 $\alpha$ was amplified using primers EF1 (ATG GGT AAG GAR GAC AAG AC) and EF2 (GGA RGT ACC AGT SAT CAT GTT) as described by O'Donnell et al. [15]. The primers used to amplify $\beta$-tubulin were BT1 (AAC ATG CGT GAG ATT GTA AGT) and BT2 (TAG TGA CCC TTG GCC CAG TTG), as described by O'Donnell and Cigelnik [16]. PCR amplification of both TEF-1 $\alpha$ and $\beta$-tubulin was carried out in a $50 \mu \mathrm{L}$ reaction containing $4.0 \mu \mathrm{L}$ buffer (Promega, Madison, WI, USA), $4.0 \mu \mathrm{L} \mathrm{MgCl}_{2}, 0.5 \mu \mathrm{L} \mathrm{dNTP} \operatorname{mix}$ (Promega), $4.0 \mu \mathrm{L}$ of each primer, $0.125 \mu \mathrm{L}$ Taq polymerase (Promega), and $0.5 \mu \mathrm{L}$ template DNA.

PCR cycle for TEF-1 $\alpha$ amplification was as follows: initial denaturation at $94{ }^{\circ} \mathrm{C}$ for $85 \mathrm{~s}$ followed by 35 cycles of denaturation at $95{ }^{\circ} \mathrm{C}$ for $35 \mathrm{~s}$, annealing at $59{ }^{\circ} \mathrm{C}$ for $55 \mathrm{~s}$, extension at $72{ }^{\circ} \mathrm{C}$ for $90 \mathrm{~s}$, and a final extension at $72{ }^{\circ} \mathrm{C}$ for $10 \mathrm{~min}$. The PCR cycle for $\beta$-tubulin amplification was as follows: initial denaturation at $94{ }^{\circ} \mathrm{C}$ for $1 \mathrm{~min}$, followed by 30 cycles at $94{ }^{\circ} \mathrm{C}$ for $30 \mathrm{~s}$, annealing at $58^{\circ} \mathrm{C}$ for $30 \mathrm{~s}$, extension at $72{ }^{\circ} \mathrm{C}$ for $1 \mathrm{~min}$, and final extension at $72{ }^{\circ} \mathrm{C}$ for $5 \mathrm{~min}$.

The ITS region was amplified using the primers ITS5 (GGA AGT AAA AGT CGT AAC AAG G) and NL4 (GGTC CGT GTT TCA AGA CGG) [17]. PCR amplification was carried out in a $50 \mu \mathrm{L}$ reaction containing $0.5 \mu \mathrm{L}$ template DNA, $4.0 \mu \mathrm{L}$ PCR buffer, $4.0 \mu \mathrm{L} \mathrm{MgCl}_{2}$, $2.0 \mu \mathrm{L}$ each of forward and reverse primers, $0.5 \mu \mathrm{L}$ dNTPs mix (Promega), and $0.125 \mu \mathrm{L}$ of Taq polymerase (Promega). The PCR cycle for amplification of the ITS region was as follows: initial denaturation at $95^{\circ} \mathrm{C}$ for $2 \mathrm{~min}$, followed by 30 cycles of denaturation at $95^{\circ} \mathrm{C}$ for $1 \mathrm{~min}$, annealing at $50{ }^{\circ} \mathrm{C}$ for $30 \mathrm{~s}$, extension at $72{ }^{\circ} \mathrm{C}$ for $2 \mathrm{~min}$, and final extension at $72{ }^{\circ} \mathrm{C}$ for $10 \mathrm{~min}$.

Agarose gel electrophoresis (1.5\%) was used to detect genomic DNA and amplified PCR products of TEF-1 $\alpha, \beta$-tubulin, and ITS region. Electrophoresis was performed at $70 \mathrm{~V}$ and $400 \mathrm{~mA}$ for $80 \mathrm{~min}$ with $1 \mathrm{X}$ TBE buffer. The agarose gel was loaded with $4 \mu \mathrm{L}$ genomic DNA or PCR product and $1 \mu \mathrm{L}$ of loading dye (Fermentas, Vilnius, Lithuania). The obtained bands were evaluated using $1 \mathrm{~kb}$ and $100 \mathrm{bp}$ DNA markers (Fermentas). After electrophoresis, the gel was viewed using Bio-RAD Molecular Imager ${ }^{\circledR}$ Gel DocTMXr system with Discovery Series TM Quantity One ${ }^{\circledR}$ 1-D Analysis software Version 4.6.5. (Bio-RAD, Hercules, CA, USA). The PCR products were sent to a service provider for DNA sequencing.

\subsubsection{Sequence and Phylogenetic Analyses}

All sequences were aligned using ClustalW included in the Molecular Evolution Genetic Analysis (MEGA5) software [18]. The consensus sequences obtained from the forward and reverse sequences were compared with other sequences in the GenBank and Fusarium-ID databases. BLAST search was performed in both databases to obtain the identity of the isolates.

Eight Fusarium species were included in the phylogenetic analysis to represent other known clades and Fusarium spp. as a reference (Table 1). 
Table 1. Fusarium species isolates included in phylogenetic analysis.

\begin{tabular}{cccc}
\hline Species/Code & Accession No. & Geographic Origin & References \\
\hline F. verticillioides & NRRL22172 & Germany & O'Donnell et al. [19] \\
F. oxysporum & NRRL22902 & USA & O'Donnell et al. [19] \\
F. proliferatum & NRRL22944 & Germany & O'Donnell et al. [19] \\
F. camptoceras & NRRL13381 & - & Proctor et al. [20] \\
F. incarnatum & NRRL31160 & - & Proctor et al. [20] \\
F. rigidiuscula & FASHPZH01 & - & Qi et al. [21] \\
F. lateritium & FRCL120 & Africa & Geiser et al. [22] \\
F. chlamydosporum & NRRL 52797 & India & O'Donnell et al. [23] \\
\hline
\end{tabular}

Phylogenetic analysis of $F$. solani was performed separately, as the isolates were more prevalent than the other Fusarium species. For phylogenetic analysis of $F$. solani isolates, other sequences representing known FSSC clades were also included (Table 2).

Multiple sequence analysis for phylogenetic analysis was also performed using MEGA 5 software. Phylogenetic analysis was carried out using the Maximum Likelihood (ML) method, as the ML method deduces an evolutionary tree by maximizing the probability of observing the data. To generate the ML tree, the complete deletion option, NearestNeighbor-interchange (NNI), and 1000 bootstrap replications were applied, and the tree was inferred by an NJ algorithm using a matrix of pair distances estimated with the Kimura model.

\subsection{Physical and Chemical Analyses of Mangrove Soil}

Several parameters of the mangrove soil samples, such as moisture, texture, $\mathrm{pH}$, salinity, carbon content, and nitrogen content, were analyzed.

\subsubsection{Soil Moisture}

The oven-dry method was used to calculate soil moisture. The moisture content in weight percent was derived using the following formula (1) [24]:

Moisture $(w t \%)=(w t$ of wet soil + tare $)-(w t$ of day soil + tare $) /(w t$ of dry soil + tare $)-($ tare $) \times 100$

\subsubsection{Soil Texture}

The pipette method [25] was used to determine the soil texture. The texture of the soil sample and percentages of clay, sand, and silt were estimated using the United States Department of Agriculture (USDA) soil textural triangle.

\subsubsection{Soil $\mathrm{pH}$}

Soil $\mathrm{pH}$ was measured for a 1:2.5 soil/water suspension [24] using a $\mathrm{pH}$ meter (MettlerToledo 320, Greifensee, Switzerland).

\subsubsection{Soil Salinity}

Soil salinity was measured in a suspension of the soil in water (1:2) using an electric conductivity). Salinity readings expressed in terms of ppt.

\subsubsection{Carbon Content}

The carbon content of the mangrove soil samples was determined using the dichromate oxidation method or the Walkley-Black method [26]. The carbon content was then calculated using the following formula (Rowell, 1994):

(i) Oxidation carbon $75 \%=$ volume blank-volume titrate $\times 0.003 \times 100 /$ weight of sample

(ii) Total carbon $(\%)=$ Oxidizable carbon $(75 \%) \times 100 / 75$

The total amount of carbon was converted using a conversion factor of 1.72 to organic matter by using the following formula: Organic matter $(\%)=$ Total carbon $\times 1.72$. 
Table 2. Fusarium solani strains included in phylogenetic analysis.

\begin{tabular}{|c|c|c|c|}
\hline Code & Accession Number & Fusarium solani & Geographic Origin \\
\hline NRRL22389 & AF178340 & Fusarium sp. & Maryland, USA \\
\hline NRRL22142 & AF178347 & $\begin{array}{l}\text { Fusarium solanif. sp. } \\
\text { cucurbitae MPV }\end{array}$ & California, USA \\
\hline NRRL 22141 & AF178329 & $\begin{array}{l}\text { Fusarium solanif. sp. } \\
\text { сuсurbitae MPV }\end{array}$ & New Zealand \\
\hline NRRL22161 & AF178330 & $\begin{array}{l}\text { Fusarium solanif. sp. } \\
\text { robiniae MPVII }\end{array}$ & Japan \\
\hline NRRL22586 & AF178353 & $\begin{array}{l}\text { Fusarium solanif. sp. } \\
\text { robiniae MPVII }\end{array}$ & Virginia, USA \\
\hline NRRL22157 & AF178359 & $\begin{array}{c}\text { Fusarium solanif. sp. mori } \\
\text { MPVIII }\end{array}$ & Japan \\
\hline NRRL22230 & AF178358 & $\begin{array}{c}\text { Fusarium solanif. sp. mori } \\
\text { MPVIII }\end{array}$ & Japan \\
\hline NRRL22278 & AF178337 & $\begin{array}{c}\text { Fusarium solanif. sp. pisi } \\
\text { MPVI }\end{array}$ & - \\
\hline NRRL22820 & AF178355 & $\begin{array}{c}\text { Fusarium solanif. sp. pisi } \\
\text { MPVI }\end{array}$ & Indiana, USA \\
\hline NRRL22579 & AF178352 & Fusarium sp. & Indonesia \\
\hline NRRL22163 & AF178382 & $\begin{array}{l}\text { Fusarium solanif. sp. } \\
\text { xanthoxyli MPIV }\end{array}$ & Japan \\
\hline NRRL22277 & AF178336 & $\begin{array}{l}\text { Fusarium solanif. sp. } \\
\text { xanthoxyli MPIV }\end{array}$ & Japan \\
\hline NRRL22402 & AF178344 & Fusarium solanif. sp. batatas & North Carolina, USA \\
\hline NRRL22400 & AF178343 & Fusarium solanif. sp. batatas & North Carolina, USA \\
\hline NRRL22101 & AF178333 & Fusarium striatum & Panama \\
\hline NRRL22166 & AF178350 & Neocosmospora vasinfecta & Illinois, USA \\
\hline NRRL22436 & AF178348 & Neocosmospora vasinfecta & South Africa \\
\hline NRRL22468 & AF178349 & Neocosmospora vasinfecta & Guinea \\
\hline NRRL22178 & AF178334 & Fusarium sp. & Venezuela \\
\hline NRRL22570 & AF178360 & Fusarium sp. & Brazil \\
\hline NRRL22098 & AF178327 & $\begin{array}{l}\text { Fusarium solanif. sp. } \\
\text { cucurbitae MPI }\end{array}$ & - \\
\hline NRRL22153 & AF178346 & $\begin{array}{l}\text { Fusarium solanif. sp. } \\
\text { cucurbitae MPI }\end{array}$ & - \\
\hline NRRL20438 & AF178332 & Fusarium ambrosium & India \\
\hline NRRL22354 & AF178338 & Fusarium sp. & French Guiana \\
\hline NRRL22396 & AF178342 & Fusarium sp. & French Guiana \\
\hline NRRL22395 & AF178341 & Fusarium sp. & Venezuela \\
\hline NRRL22412 & AF178351 & Fusarium sp. & French Guiana \\
\hline NRRL22387 & AF178339 & Fusarium sp. & French Guiana \\
\hline NRRL22574 & AF178345 & Fusarium sp. & Guatemala \\
\hline NRRL22158 & AF178331 & Fusarium martii-phaseoli & New York, USA \\
\hline NRRL22275 & AF178335 & Fusarium martii-phaseoli & - \\
\hline NRRL22823 & AF178356 & $\begin{array}{l}\text { Fusarium solanif. sp. } \\
\text { glycines }\end{array}$ & Indiana, USA \\
\hline NRRL22825 & AF178357 & $\begin{array}{l}\text { Fusarium solanif. sp. } \\
\text { glycines }\end{array}$ & Indiana, USA \\
\hline NRRL22632 & AF178354 & Nectria plagianthi & New Zealand \\
\hline NRRL22090 & AF178326 & Nectria illudens & New Zealand \\
\hline NRRL22316 & AF178361 & Fusarium staphyleae & New Jersey, USA \\
\hline
\end{tabular}

\subsubsection{Nitrogen Content}

The Kjeldahl method was used to determine the nitrogen content [24] of the mangrove soil samples. The amount of nitrogen was determined using the following formula (2):

Total nitrogen $=$ volume of acid used in the titration process $(\mathrm{mL}) \times 100 /$ weight 


\subsection{Statistical Analyses}

All data were analyzed using Statistical Package for the Social Sciences (SPSS) software. One-way ANOVA was applied to compare soil properties at different sampling locations. Duncan's multiple-range test was used to compare different properties of the mangrove soil samples. This analysis was based on the comparison of three or more means that differ significantly in an analysis of variance. The $\mathrm{T}$ test was used to compare mangrove soil sample properties between soil samples from sampling sites in the states of Penang and Kedah.

\section{Results}

\subsection{Fusarium Isolates}

Debris isolation yielded the highest number of Fusarium isolates (51\%), followed by direct isolation $(48 \%)$ and soil dilution plate isolation (1\%). A total of 124 isolates of Fusarium were recovered and tentatively identified as F. solani $(n=77)$, F. proliferatum $(n=14)$, F. verticillioides $(n=12)$, F. incarnatum $(n=10)$, F. oxysporum $(n=3)$, F. camptoceras $(n=2)$, F. lateritium $(n=4)$, and F. decemcellulare $(n=2)$.

\subsection{PCR Amplification and Sequence Analysis of TEF-1 $\alpha$ Gene}

Successful amplification of TEF-1 $\alpha$ using EF1 and EF2 primer pairs was confirmed by the presence of a single $750 \mathrm{bp}$ band using agarose gel electrophoresis.

Based on a BLAST search of TEF-1 $\alpha$ sequences, the isolates were molecularly identified as FSSC $(n=77), F$. verticillioides $(n=20)$, F. incarnatum $(n=10)$, F. proliferatum $(n=7)$, F. lateritium $(n=4)$, F. oxysporum $(n=3)$, F. rigidiuscula $(n=2)$, and F. camptoceras $(n=1)$. All the sequences were deposited in the Genbank and the accession numbers are shown in Supplementary Table S2. BLAST results based on the Genbank and Fusarium-ID databases are shown in Table S3 (FSSC) and Table S4 (other Fusarium species).

\subsection{PCR Amplification and Sequence Analysis of $\beta$-Tubulin Gene and ITS Region}

A single band of $900 \mathrm{bp}$ observed after amplification of ITS region in the FSSC isolates $(n=77)$. An approximately $650 \mathrm{bp}$ fragment of $\beta$-tubulin was amplified using BT1 and BT2 primers in the other Fusarium species. BLAST search results of $\beta$-tubulin gene and ITS sequences are shown in Table S3 and accession numbers in Table S2.

\subsection{Phylogenetic Analysis of FSSC Isolates Based on Combined TEF-1 $\alpha$ and ITS Sequences}

The ML tree generated based on combined TEF- $1 \alpha$ and ITS sequences revealed diverse phylogenetic affinities among FSSC isolates from mangrove soils. The isolates were grouped into seven clades 1, 2, 3, 4, 5, 6, and 7 (Figure 1). Only isolates in clades 5 and 6 were grouped with F. solani reference strains described by O'Donnell [19]. Other FSSC isolates (Clades 1, 2, 3, 4, and 7) from mangrove soil did not group with any of the reference strains described by O'Donnell [19].

Four FSSC isolates (DEB16, DE10, DE12, and DE25) were grouped with two reference strains, Fusarium sp. 22354 and F. ambrosium NRRL20438 in clade 5. Four other isolates (DI20, DI10, DI18, and DI19A) in clade 6 were clustered with the reference strain of F. striatum NRRL22101 (Panama) member of clade 3 of F. solani-Nectria haematococca clades and had $98 \%-99 \%$ similarity with $N$. ipomoeae.

\subsection{Phylogenetic Analysis of Fusarium Species Based on Combined TEF-1 $\alpha$ and $\beta$-Tubulin Sequences}

In the ML tree analysis, isolates belonging to the same species were grouped in the same clade (Figure 2). The tree was divided into three main clades, I, II, and III. Main clade I consisted of F. verticillioides (sub-clade IA), F. oxysporum (sub-clade IB), and F. proliferatum (sub-clade IC) isolates; clade II comprised F. lateritium (sub-clade IIA), F. camptoceras, and F. incarnatum (sub-clade IIB); and clade III consisted of only F. rigidiuscula (Figure 2). 


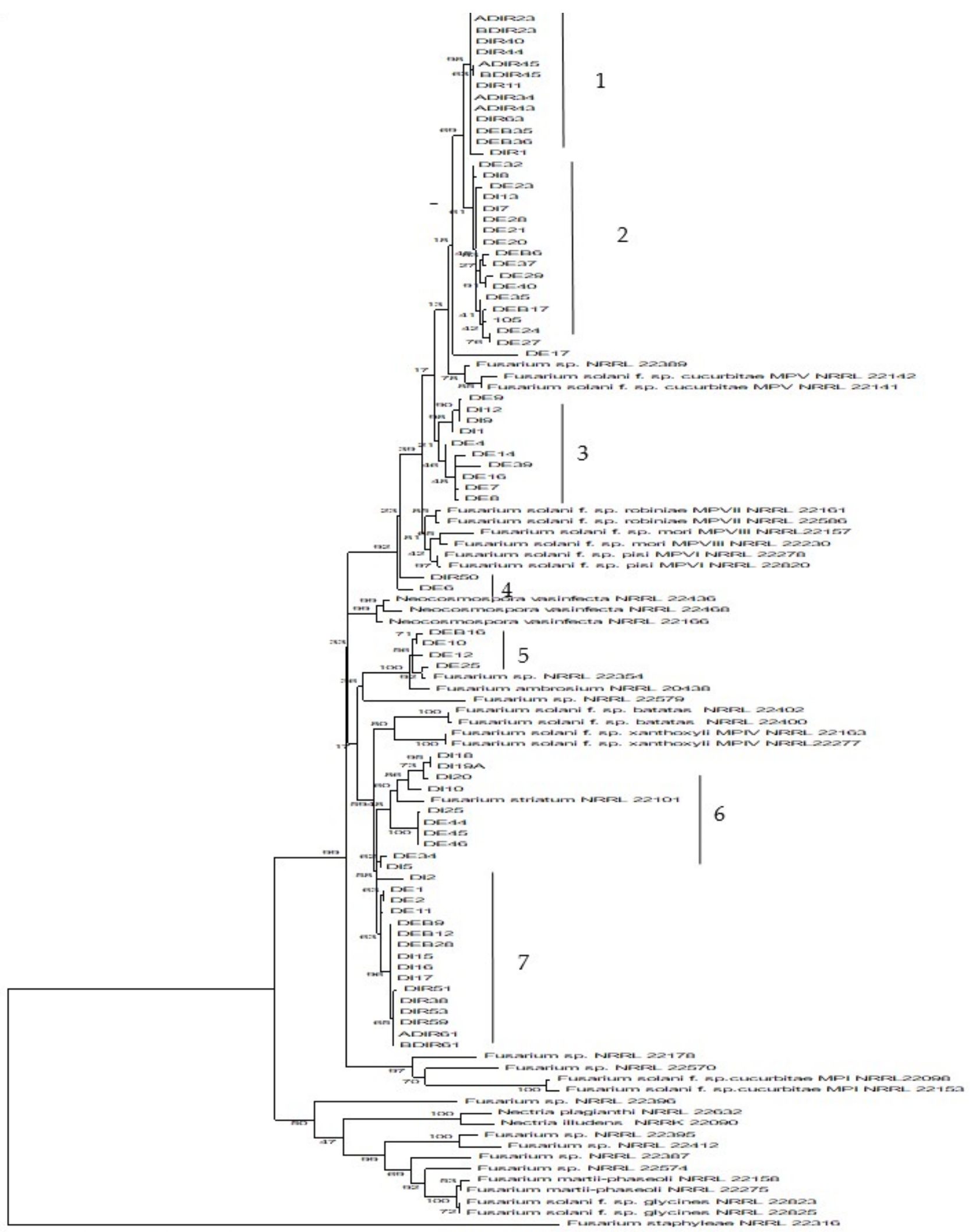

Figure 1. Maximum likelihood tree of 77 isolates of $F$. solani species complex (FSSC) isolated from mangrove soil samples and strains from Genbank based on combined sequences of ITS and TEF- $\alpha$ using Kimura 2+ I parameter method. FSSC isolates are grouped in seven clades (1-7). 


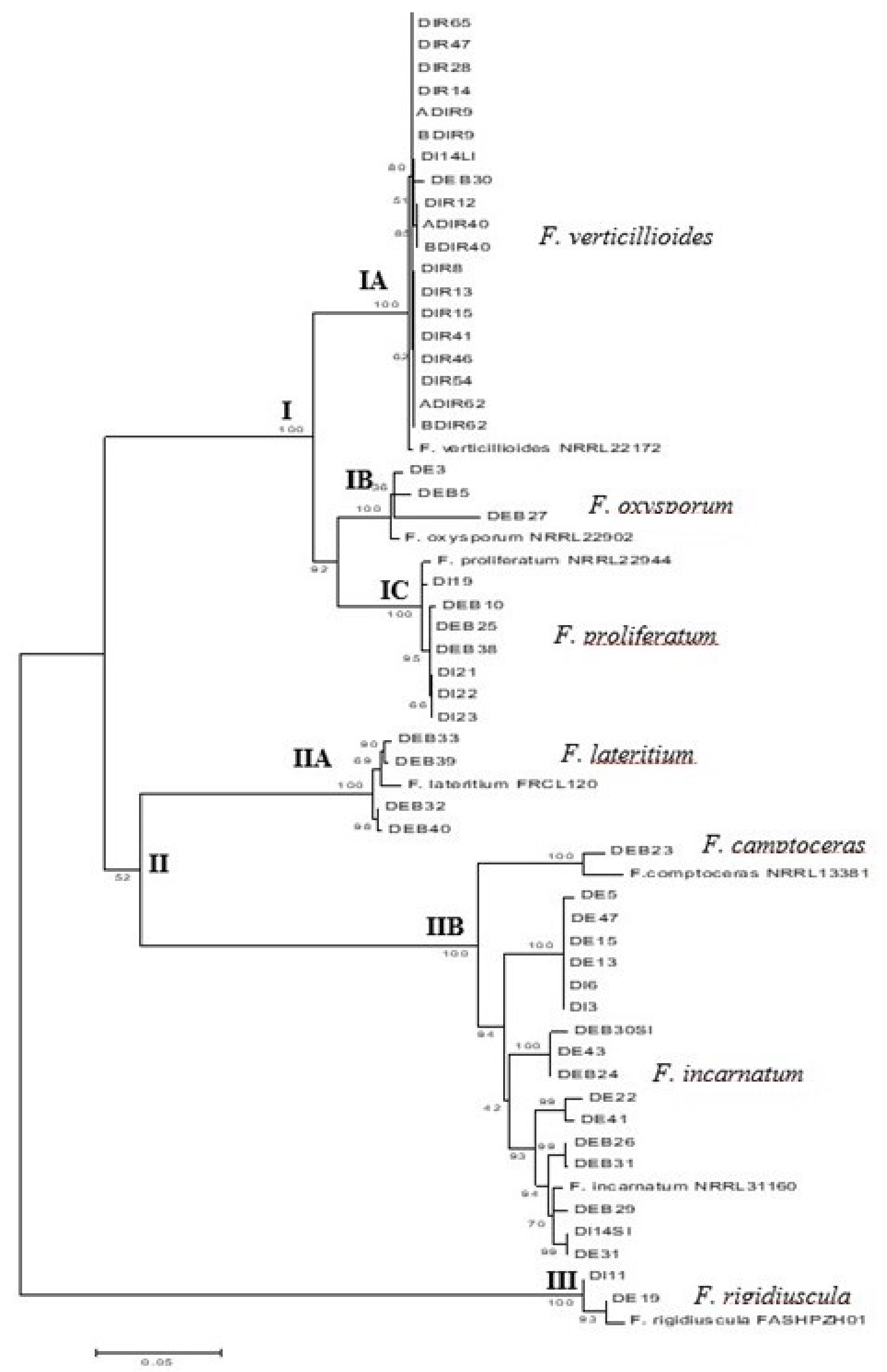

Figure 2. Maximum likelihood tree of Fusarium species from mangrove soil samples based on $\beta$-tubulin and TEF- $\alpha$ sequences. The percentage of bootstrap value was higher than $50 \%$ are shown next to the branches. The Fusarium spp. are grouped in three main clades (I, II and III) with several sub-clades (IA, IB, IC, IIA and IIB). 
Therefore, based on molecular identification, the most common species recovered from the mangrove soil samples was FSSC $(n=77)$, followed by F. verticillioides $(n=20)$, F. incarnatum $(n=10)$, F. proliferatum $(n=7)$, F. lateritium $(n=4)$, F. oxysporum $(n=3)$, F. rigidiuscula $(n=2)$, F. chlamydosporum $(n=1)$, and F. camptoceras $(n=1)$.

\subsection{Soil Analysis}

The results of mangrove soil physical and chemical analyses, Fusarium species identified at each sampling site, and the total number of isolates of each species are presented in Table 3. Seven Fusarium species were recovered from PB3 in Pulau Burung, Penang, namely FSSC, F. verticillioides, F. incarnatum, F. proliferatum, F. oxysporum, F. chlamydosporum, and F. camptoceras. The highest number of Fusarium isolates was recovered from Pantai Acheh, Penang, with 48 isolates.

\subsubsection{Soil Moisture}

Soil moisture content significantly differed between the sampling locations $(p<0.05)$. Soil moisture content was $2.59 \%-3.7 \%$ in Penang (PG and PB) and $1.6 \%-4.8 \%$ in Kedah (KPM, KBL, S1SM, S2SM, and KSG). Moisture content at KBL was significantly different from that at the other sampling locations.

There was no significant difference in soil moisture content between sampling locations in Penang and Kedah. The highest number of isolates $(n=40)$ occurred at PG with a moisture content of 3.07\%. Seven Fusarium species were identified at PB3 with a moisture content of $3.3 \%$ (Table 3 ).

\subsubsection{Soil Texture}

The mangrove soil samples from Penang were sandy loam soil, while those from Kedah varied from sandy loam and silt loam to sandy clay loam (Table 3).

\subsubsection{Soil pH}

The $\mathrm{pH}$ value of the mangrove soil samples ranged from neutral to acidic, and significant differences were observed between sampling locations $(p<0.001)$. At two sampling sites, PG and PB, in Penang the soil pH was neutral to slightly acidic (pH 6.22-7.5), while at five sampling sites (KPM, KBL, S2SM S1SM, and KSG) in Kedah it was acidic (pH 5.02-6.6) (Table 3).

There was a significant difference $(p<0.05)$ in $\mathrm{pH}$ between Penang and Kedah sampling sites. Seven Fusarium species were obtained from PB3 in Penang with a soil pH of 7.02 .

\subsubsection{Soil Salinity}

Analysis of soil salinity showed a significant difference between sampling locations $(p<0.05)$. The soil salinity differences were within moderate values ranging from 10.02 to $18.0 \mathrm{ppt}$ at all sampling locations, except at one site (PG3) with higher salinity of $21.36 \mathrm{ppt}$ where the highest number of Fusarium isolates recovered $(n=40)$. Seven Fusarium species were recovered at PB3 with a salinity of $19.08 \mathrm{ppt}$.

\subsubsection{Carbon Content}

Significant variations in soil carbon content were detected between the sampling locations $(p<0.001)$. The carbon content in two sites, PG and PB in Penang ranged from $49 \mathrm{mg} / \mathrm{g}$ to $138 \mathrm{mg} / \mathrm{g}$, while that in KPM, KBL, S1SM, S2SM, and KSG in Kedah ranged from $15.75 \mathrm{mg} / \mathrm{g}$ to $58.0 \mathrm{mg} / \mathrm{g}$ (Table 3). The carbon content between sampling sites in Penang and Kedah showed a significant difference $(p<0.05)$.

Seven Fusarium species were found at PB3, however, the highest number of isolates $(n=48)$ was obtained from PG (Table 3). 
Table 3. Mangrove soil properties and Fusarium species isolates.

\begin{tabular}{|c|c|c|c|c|c|c|c|c|c|}
\hline $\begin{array}{c}\text { State } \\
\text { (Location) }\end{array}$ & $\begin{array}{l}\text { Sampling } \\
\text { Site }\end{array}$ & Soil Texture & $\begin{array}{c}\text { Carbon Content } \\
(\mathrm{mg} / \mathrm{g})\end{array}$ & $\begin{array}{c}\text { Nitrogen Content } \\
(\mathrm{mg} / \mathrm{g})\end{array}$ & $\begin{array}{l}\text { Soil } \\
\text { pH }\end{array}$ & $\begin{array}{c}\text { Soil Moisture } \\
(\%)\end{array}$ & $\begin{array}{l}\text { Soil Salinity } \\
\quad(p p t)\end{array}$ & $\begin{array}{c}\text { Fusarium Species } \\
\text { (Number of Isolates) }\end{array}$ & Total \\
\hline \multirow{3}{*}{$\begin{array}{c}\text { Penang } \\
\text { (Pantai Acheh, } \\
\text { Balik Pulau }\end{array}$} & PG1 & Loamy sand & $71.8 \pm 0.9$ & $2.3 \pm 0.1$ & $7.33 \pm 0.01$ & 2.59 & $17.39 \pm 4.7$ & $\begin{array}{c}\text { F. solani (3) } \\
\text { F. lateritium (2) } \\
\text { F. proliferatum (1) }\end{array}$ & \multirow{2}{*}{$\begin{array}{c}48 \\
(35 \%)\end{array}$} \\
\hline & PG2 & Sandy loam & $60.96 \pm 1.2$ & $1.8 \pm 0$ & $7.53 \pm 0.39$ & 3.71 & $16.49 \pm 1.4$ & $\begin{array}{c}\text { F. solani }(1) \\
\text { F. longipes (1) }\end{array}$ & \\
\hline & PG3 & Sandy loam & $49.52 \pm 0.6$ & $1.9 \pm 0$ & $7.29 \pm 0.01$ & 3.07 & $21.36 \pm 0.6$ & $\begin{array}{c}\text { F. solani (22) } \\
\text { F. verticillioides (18) }\end{array}$ & \multirow[b]{4}{*}{$\begin{array}{c}18 \\
(13 \%)\end{array}$} \\
\hline \multirow[b]{3}{*}{$\begin{array}{c}\text { Penang } \\
\text { (Pulau Burung, } \\
\text { Seberang Perai) } \\
\text { Pinang } \\
\text { (Pulau Burung, } \\
\text { Seberang Perai) }\end{array}$} & PB1 & Sandy loam & $138 \pm 1.6$ & $4.0 \pm 0$ & $6.22 \pm 0.19$ & 3.64 & $16.72 \pm 0.5$ & F. lateritium (2) & \\
\hline & PB2 & Sandy loam & $84.5 \pm 0.3$ & $1.33 \pm 0.4$ & $7.14 \pm 0.06$ & 2.43 & $16.24 \pm 0.05$ & F. oxysporum (1) & \\
\hline & PB3 & Sandy loam & $113 \pm 8.6$ & $3.4 \pm 0.2$ & $7.02 \pm 0.06$ & 3.3 & $19.08 \pm 2.9$ & $\begin{array}{l}\text { F. solani (4) } \\
\text { F. verticillioides (1) } \\
\text { F. incarnatum (5) } \\
\text { F. proliferatum (2) } \\
\text { F. oxysporum (1) } \\
\text { F. chlamydosporum (1) } \\
\text { F. camptoceras (1) }\end{array}$ & \\
\hline \multirow{3}{*}{$\begin{array}{c}\text { Kedah } \\
\text { Kampung Pantai } \\
\text { Merdeka }\end{array}$} & KPM1 & Sandy loam & $31.93 \pm 0.7$ & $1.7 \pm 0.2$ & $6.61 \pm 0.01$ & $3.6 \pm 0.5$ & $18.91 \pm 4.3$ & F. solani (4) & \multirow{3}{*}{$\begin{array}{c}13 \\
(9 \%)\end{array}$} \\
\hline & KPM2 & Sandy loam & $21.03 \pm 1.2$ & $1.33 \pm 0.1$ & $6.12 \pm 0.05$ & $1.83 \pm 0$ & $18.31 \pm 0.1$ & $\begin{array}{l}\text { F. solani (5) } \\
\text { F. incarnatum (3) } \\
\text { F. oxysporum (1) }\end{array}$ & \\
\hline & KPM3 & Loam & $19.45 \pm 0.8$ & $1.6 \pm 0.2$ & $5.97 \pm 0.01$ & $2.14 \pm 0.3$ & $16.52 \pm 0.22$ & 0 & \\
\hline \multirow{3}{*}{$\begin{array}{c}\text { Kedah } \\
\text { Kampung Batu } \\
\text { Lintang }\end{array}$} & KBL1 & Silt loam & $35.58 \pm 0.8$ & $2.46 \pm 0.1$ & $5.72 \pm 0.02$ & $4.82 \pm 0.4$ & $10.61 \pm 0.5$ & $\begin{array}{l}\text { F. solani (13) } \\
\text { F. incarnatum (3) } \\
\text { F. rigidiuscula (1) }\end{array}$ & \multirow{3}{*}{$\begin{array}{c}17 \\
(12 \%)\end{array}$} \\
\hline & KBL2 & Sandy loam & $47.36 \pm 2.7$ & $2.46 \pm 0.1$ & $5.4 \pm 0.03$ & $3.9 \pm 0.2$ & $17.62 \pm 0.07$ & 0 & \\
\hline & KBL3 & Sandy loam & $32.016 \pm 1$ & $2.0 \pm 0$ & $5.27 \pm 0.09$ & $2.77 \pm 0.1$ & $13.37 \pm 0.02$ & F. merismoides (1) & \\
\hline
\end{tabular}


Table 3. Cont.

\begin{tabular}{|c|c|c|c|c|c|c|c|c|c|}
\hline $\begin{array}{c}\text { State } \\
\text { (Location) }\end{array}$ & $\begin{array}{l}\text { Sampling } \\
\text { Site }\end{array}$ & Soil Texture & $\begin{array}{c}\text { Carbon Content } \\
(\mathrm{mg} / \mathrm{g})\end{array}$ & $\begin{array}{c}\text { Nitrogen Content } \\
(\mathrm{mg} / \mathrm{g})\end{array}$ & $\begin{array}{l}\text { Soil } \\
\text { pH }\end{array}$ & $\begin{array}{l}\text { Soil Moisture } \\
(\%)\end{array}$ & $\begin{array}{l}\text { Soil Salinity } \\
\text { (ppt) }\end{array}$ & $\begin{array}{l}\text { Fusarium Species } \\
\text { (Number of Isolates) }\end{array}$ & Total \\
\hline \multirow{3}{*}{$\begin{array}{c}\text { Kedah } \\
\text { Semeling1 Sungai } \\
\text { Merbok }\end{array}$} & S1SM1 & Clay loam & $28.61 \pm 2.5$ & $2.6 \pm 0$ & $5.02 \pm 0.01$ & $1.62 \pm 0.4$ & $11.99 \pm 0.6$ & F. solani (1) & \multirow{3}{*}{$\begin{array}{c}2 \\
(1.4 \%)\end{array}$} \\
\hline & S1SM2 & Sandy loam & 58. $\pm 27 \pm 1$ & $1.6 \pm 0$ & $5.33 \pm 0.02$ & $3.08 \pm 0.4$ & $13.2 \pm 0.22$ & 0 & \\
\hline & S1SM3 & Sandy loam & $28.86 \pm 0.1$ & $1.8 \pm 0.1$ & $5.36 \pm 0$ & $1.7 \pm 0.08$ & $10.25 \pm 0.04$ & F. rigidiuscula (1) & \\
\hline \multirow{2}{*}{$\begin{array}{c}\text { Kedah } \\
\text { Semeling2 Sungai } \\
\text { Merbok }\end{array}$} & S2SM 1 & Sandy clay loam & $45.59 \pm 0.4$ & $2.1 \pm 0.11$ & $5.31 \pm 0.01$ & $2.66 \pm 0.2$ & $12.78 \pm 0.6$ & $\begin{array}{c}\text { F. solani (4) } \\
\text { F. incarnatum (2) }\end{array}$ & \multirow{2}{*}{$\begin{array}{c}20 \\
(14 \%)\end{array}$} \\
\hline & S2SM 3 & Sandy loam & $27.69 \pm 7.5$ & $2 \pm 0$ & $5.57 \pm 0.03$ & $1.82 \pm 0.2$ & $10.02 \pm 0.15$ & $\begin{array}{c}\text { F. solani }(1) \\
\text { F. longipes (1) }\end{array}$ & \\
\hline \multirow{3}{*}{$\begin{array}{c}\text { Kedah } \\
\text { Segantang Garam } \\
\mathbf{h} \\
\text { Segantang Garam }\end{array}$} & KSG1 & Loam & $20.4 \pm 0.13$ & $2.06 \pm 0.1$ & $5.98 \pm 0.07$ & $4.21 \pm 0.1$ & $13.02 \pm 0.3$ & F. solani (1) & \multirow{3}{*}{$\begin{array}{c}18 \\
(13 \%)\end{array}$} \\
\hline & KSG2 & Silt loam & $42.75 \pm 0.7$ & $1.6 \pm 0$ & $6.12 \pm 0.01$ & $2.94 \pm 0.0$ & $11.36 \pm 0.8$ & $\begin{array}{l}\text { F. solani (10) } \\
\text { F. incarnatum (1) } \\
\text { F. proliferatum (2) } \\
\text { F. longipes (1) }\end{array}$ & \\
\hline & KSG3 & Silt loam & $26.85 \pm 0.5$ & $2.06 \pm 0.1$ & $6.133 \pm 0$ & $4.0 \pm 0.7$ & $13.33 \pm 0.3$ & F. proliferatum (3) & \\
\hline
\end{tabular}




\subsubsection{Nitrogen Content}

The nitrogen content in the soil samples did not significantly differ among the sampling locations. The highest nitrogen content of $4.0 \mathrm{mg} / \mathrm{g}$ was recorded at the PB1 in Penang and two isolates of F. lateritium were recovered there (Table 3).

\section{Discussion}

Most of the Fusarium species reported in this study were isolated using the debris isolation method, which yielded the highest number of isolates from the mangrove soil samples. Debris in mangrove soil consists of plant roots, dried leaves, stems, and branches, which often serve as habitats for saprophytic and parasitic fungi that can exist as discrete propagules, such as chlamydospores and resistant conidia [2]. Most Fusarium species produce chlamydospores, resistant conidia, and resistant hyphae in the soil, which germinate under suitable conditions, such as nutrient availability [27]. Additionally, carbon-rich soils can harbor adherent conidia and fungal fragments for extended periods of time.

Phylogenetic analysis of FSSC isolates from mangrove soil suggested that several isolates might represent new phylogenetic species or distinct lineages of $F$. solani residing in mangrove soil as isolates in clades 1, 2, 3, 4, and 7 did not group with any clade or lineage described by O'Donnell [19]. New phylogenetic lineages of $F$. solani from native soils have been reported by Nalim et al. [28], who collected $F$. solani isolates from the soil of primary forests in Sri Lanka and tropical Australia. The F. solani isolates formed new novel clades within clade 3 [19]. New phylogenetic clades or lineages were previously reported by Bogale et al. [29], Nalim et al. [28], and Chehri [30] indicating that F. solani contains numerous phylogenetic lineages. The numerous phylogenetic lineages of $F$. solani might be associated with the widespread occurrence and distribution of FFSC, of which this species has a cosmopolitan distribution and is a common soil inhabitant.

Phylogenetic analysis of FSSC isolates also suggested four FSSC isolates from mangrove soil were related to $N$. ipomoeae, which is a well-known saprophyte and pathogen causing stem rot in eggplant and sweet potato. These FSSC isolates were clustered with the reference strain of $F$. striatum NRRL 22101 (Panama) member of clade 3 described by O'Donnell (2000). F. striatum is an anamorph of Haematonectria ipomoeae (Halst) [31] and is synonymous with Nectria ipomoeae [32].

FSSC isolates are common soil inhabitant and have been isolated from a variety of soil types, including subtropical and semi-arid grassland soil [33], saline soil [34], peat soil [4], native soils in Sri Lanka and tropical Australia [28], cultivated soil [35], and agriculture soil [29].

F. verticillioides and F. proliferatum are closely related, as both are members of the FFSC, whereas F. oxysporum is considered a sister group of the FFSC $[16,19]$. These three species are widely distributed and have been recovered from various hosts or substrates. Both F. verticillioides and F. proliferatum are well-known plant pathogens associated with corn ear rot. Furthermore, there are several reports on F. verticillioides and F. proliferatum isolated from non-agricultural soils [13,36-38]. The occurrence of both $F$. verticillioides and $F$. proliferatum in mangrove soil might be attributed to the dispersal of infected plant materials via wind.

F. oxysporum is a common soil saprophyte that has been isolated from agricultural soil [14], cultivated, and temperate soils [39,40]. Similar to F. verticillioides and F. proliferatum, the dispersal of F. oxysporum to mangrove areas might be through infected planting material; however, this species produces chlamydospores and conidia to ensure long-term survival in the soil and plant debris, which can be dispersed via wind, soils, and seeds [41].

F. incarnatum and F. camptoceras isolates are part of the Fusarium incarnatum-equiset $i$ species complex (FIESC); however, based on a study by Xia et al. [42], F. camptoceras formed three lineages that are distinct from FIESC. F. camptoceras was reported from fynbos soils [43] and the distribution of this species is restricted to tropical and sub-tropical areas [14].

Similar to FSSC isolates, F. incarnatum is also widespread, commonly found in the tropics and subtropics, but has also been reported in the Mediterranean and in temperate 
areas [14]. It is a common soil inhabitant that has been recovered from peat soil [44], sandy soil [45], and Arctic soil [6].

F. lateritium occurs in soil worldwide [14] and has been reported in soil samples from different altitudes in the Transkei, Southern Africa [46], soil planted with millet and sorghum from Lesotho, Nigeria, and Zimbabwe [47], and from and in desert zones of Dead Sea Valley [48].

As F. rigidiuscula (syn F. decemcellulare) is frequently found in tropical regions, it is not surprising that this species was isolated from mangrove soil. Most reports on F. rigidiuscula are associated with plant diseases, including the death and gall in mango trees and bark canker of hardwood trees. F. decemcellulare was also found in non-agricultural garden soil samples from Hormozgan province, Iran [49].

The number of Fusarium isolates and species recovered from each sampling location in the present study varied. This variation might be related to the soil physical and chemical properties, such as soil moisture, soil $\mathrm{pH}$, carbon and nitrogen content, and soil texture, as these factors influence the distribution of fungal diversity in the soil.

The highest number of Fusarium isolates identified were in sandy loam soils. Sandy loam soil has high moisture content and aeration, which are suitable for the growth of microorganisms. Soil texture is one of the most important factors influencing the structure of microbial communities, including fungi. Kara and Bolat [50] studied the effect of soil compaction on microfungal community structure and reported that the frequency of the genus Fusarium was greatly increased in sandy loam soil.

Panda et al. [51] reported the influence of soil total carbon, total nitrogen, $\mathrm{pH}$, temperature, moisture, and surface vegetation on soil microflora in a coastal, sandy belt of India, and concluded that carbon content positively affects fungal populations, including Fusarium species. Soil carbon content is a vital source of energy for the inhabitant microorganisms that inhabit the soil. Organic matter serves two functions for microorganisms in soils, providing energy for growth and supplying carbon for the formation of new cells [52]. The results of the present study were similar to those reported by Swer et al. [53], who stated that the fungal population is positively influenced by organic carbon, which can play an essential role in growth, sporulation, and diversity. The carbon content at the sampling sites in Kedah was significantly lower than that in Penang. The number of Fusarium isolates recovered in all sampling locations in Kedah was less than that in Penang, wherein F. solani and F. incarnatum were the prevalent species. These two species are well known soil fungi and can be found in various soil environments, such as in tropical and subtropical regions [14] and are capable of tolerating unsuitable conditions as they produce chlamydospores that can withstand extreme conditions [2] such as less nutrition, desiccation, anaerobic conditions, and high temperature. Fusarium isolates were not recovered at several sampling sites (PB1, KBL2, and SISM2), which had high carbon content, may be due to competition with other microorganisms. According to Leslie and Summerell [14] the population structure of Fusarium spp. in non-cultivated and cultivated soils depends on several factors, including the capacity to colonize different plant hosts and to compete saprophytically with other microbial communities.

The nitrogen content in all mangrove soil samples, did not differ significantly. It is possible that high nitrogen content in the soil increases fungal sporulation and hyphal growth rate [54], which contributes to the occurrence of Fusarium isolates in the mangrove soils. Joshi and Chauhan [55] studied the distribution of microfungi in various soil types from Chambal ravines, India and reported a significant positive influence of nitrogen content on fungal populations, including Fusarium.

Soil pH strongly influences the availability of carbon and nutrients as well as the solubility of metals. Fungi, including Fusarium, exhibit a wider $\mathrm{pH}$ range from 2 to 10 for optimal growth [56]. A significant difference in $\mathrm{pH}$, ranging from acidic to neutral, was detected between the sampling locations. Several studies have shown that the $\mathrm{pH}$ of mangrove soils can range from acidic to alkaline. Gonzalez-Acosta et al. [57] and Thatoi et al. [58] reported nominal alkalinity in the Mexican mangrove forest and slight alkalinity 
in Bhitarkanika Odisha mangrove sediment samples, respectively. Notably, microbial groups differ in their responses to soil $\mathrm{pH}$, and a few studies have reported the impact of soil pH on fungal communities and their occurrences. Wheeler et al. [59] and Nevarez et al. [60] pointed out that fungal species typically have a wide range of optimum $\mathrm{pH}$, often ranging from $\mathrm{pH} 5$ to 9 , without significant inhibition of their growth. Nazim et al. [61] stated that fungi were capable of enduring acidic conditions and were equally abundant in acidic and neutral soils, which was similar to the present study findings. Maina et al. [62] studied the effect of $\mathrm{pH}$ on different types of soils in Taita Taveta District, Kenya, focusing on the distribution and diversity of Fusarium species, and concluded that there was a positive effect of $\mathrm{pH}$ levels and the occurrence and abundance of Fusarium.

Soil salinity was found to be significantly different among sampling locations, but remained within a moderate range of 5-18 ppt. The two most prevalent Fusarium species, FSSC and F. verticillioides, were recovered from a sampling site with a slightly high salinity of 21.36 ppt suggesting that the effect of salinity may have altered the competitive ability of other microbes in the soil. Mandeel [34] studied the biodiversity of the genus Fusarium in saline soil habitats in Bahrain and identified five Fusarium species, F. solani, F. oxysporum, F. chlamydosporum, F. longipes, and F. compactum, of which F. solani was dominant and could tolerate high salinity conditions.

Soil microbial biomass can be limited by soil moisture under both dry and wet conditions. Mandeel [34] reported that Fusarium species recovered from saline habitats in Bahrain was influenced by soil moisture. Banakar et al. [63] concluded that soil moisture negatively affected soil fungi populations, including Fusarium, from dry deciduous forest. Oritsejafor [64] reported that the highest survival of F. oxysporum as a pathogen was recorded at the lowest level of soil moisture tested (15\%), which indicates that Fusarium spp. are strongly aerobic, and that Fusarium population can be reduced by maintaining the soil in a saturated condition. Fusarium could not be isolated from soil submerged in water for 12 weeks.

Fusarium spp. in mangrove soil are likely saprophytes involved in many aspects of degradation of organic materials, nutrient cycling, and energy flow in mangrove ecosystems. Among the Fusarium species identified, FSSC, F. oxysporum, F. verticillioides, and F. proliferatum are well-known plant pathogens that cause vascular wilt, stem and root rot, blight, and damping-off in various agricultural crops. Moreover, Fusarium is capable of infecting plants as well as humans, an event known as trans-kingdom pathogenicity [65]. Fusarium species also cause opportunistic infections in humans, including superficial (keratitis and onychomycosis), locally invasive, or disseminated infections, particularly in immunocompromised individuals [66]. Most of the reported opportunistic human pathogens are FSSC, F. oxysporum, and occasionally F. incarnatum, F. proliferatum, F. verticillioides, and F. chlamydosporum [66,67]. Thus, the present study suggests that mangrove soil can be a reservoir for plant and human pathogens, or sources of inoculum for plant disease and human pathogens.

To summarize, F. solani species complex (FSSC), F. oxysporum, and F. incarnatum are common soil inhabitants and are regarded as cosmopolitan species. F. verticillioides, F. lateritium, and F. proliferatum are also widely distributed worldwide. These species have the ability to occupy and adapt to a wide range of ecological conditions that contribute to their widespread distribution [68]. According to Smith [69], widespread distribution of Fusarium spp. might be related to their ability to breakdown and digest various complex carbohydrates and proteins, tolerate adverse climatic conditions, and withstand rather high levels of toxic substances, such as ammonia, antibiotics, and fungicides, which can eradicate other microbes.

\section{Conclusions}

The present study identified several Fusarium species in mangrove soil from northern region of Peninsular Malaysia. Based on analyses of soil physico-chemical properties, carbon content, $\mathrm{pH}$, soil moisture, and salinity, varied between the sampling locations, 
but nitrogen content did not show any significant difference between all locations and between the sampling sites from states of Penang and Kedah. The present study found that regardless of the soil physical and chemical properties, mangrove soils harbor various species of Fusarium, with FSSC being the most prevalent. Some species, such as FSSC, F. oxysporum, F. incarnatum, F. verticillioides, F. lateritium, and F. proliferatum are distributed worldwide and occur in various hosts and substrates. The various Fusarium species residing in mangrove soils are likely saprophytes and may have an indirect effect on plants and humans. The species recovered from mangrove soils have the potential for causing plant diseases under suitable environmental conditions as well as becoming opportunistic human pathogens, thereby posing additional threat to immunocompromised individuals. The present results also indicate that mangrove soil may be a source of inoculum for plant and human pathogenic Fusarium species. Moreover, the diverse species of Fusarium recovered from mangrove soil adds to the available data on the diversity of the genus Fusarium, particularly in non-agricultural environments.

Supplementary Materials: The following are available online https:/ / www.mdpi.com/2076-260 7/9/3/497/s1; Table S1. Sampling locations of mangrove soil samples collected in the northern states of Penang and Kedah, Peninsular Malaysia, Table S2. Accession numbers of TEF- $1 \alpha$, ITS and $\beta$-tubulin sequences of all Fusarium species, Table S3. BLAST search results and percentage of similarity of TEF-1 $\alpha$ sequences (FFSC and other Fusarium species) based on the Genbank and Fusarium-ID databases, Table S4. BLAST search results and percentage of similarity of ITS and $\beta$-tubulin sequences (FFSC).

Author Contributions: Conceptualization, L.Z. and W.S.M.Z.; Methodology, L.Z., W.S.M.Z., M.H.M. and N.M.I.M.N.; Software, L.Z., W.S.M.Z., M.H.M. and N.M.I.M.N.; Validation, L.Z., M.H.M. and N.M.I.M.N.; Formal Analysis, L.Z. and W.S.M.Z.; Investigation, L.Z. and W.S.M.Z.; Resources, L.Z.; Data Curation, L.Z. and W.S.M.Z.; Writing-L.Z. Original Draft Preparation, W.S.M.Z.; WritingReview \& Editing, L.Z; Visualization, L.Z.; Supervision, L.Z. and M.H.M.; Project Administration, L.Z., Funding Acquisition, L.Z. All authors have read and agreed to the published version of the manuscript.

Funding: This research was funded by Research University (RUI) grant 1001/PBIOLOGI/811179.

Institutional Review Board Statement: Not applicable.

Informed Consent Statement: Not applicable.

Data Availability Statement: The data presented in this study are available on request from the corresponding author.

Acknowledgments: The authors are grateful for the administrative and technical support received from School of Biological Sciences, Universiti Sains Malaysia.

Conflicts of Interest: The authors declare no conflict of interest.

\section{References}

1. Al-Hatmi, A.M.S.; Bonifaz, A.; De Hoog, G.S.; Vazquez-Maya, L.; Garcia-Carmona, K.; Meis, J.F.; Van Diepeningen, A.D. Keratitis by Fusarium temperatum, a novel opportunist. BMC Infect. Dis. 2014, 14, 588. [CrossRef]

2. Burgess, L.W. General ecology of the Fusaria. In Fusarium: Diseases, Biology, and Taxonomy; Nelson, P.E., Toussoun, T.A., Cook, R.J., Eds.; University Park, The Pennsylvania State University: State College, PA, USA, 1981; pp. 225-235.

3. Burgess, L.W.; Bryden, W.L. Fusarium: A ubiquitous fungus of global significance. Microbiol. Aust. 2012, 22-25. [CrossRef]

4. Latiffah, Z.; Izzati, H.N.; Baharuddin, S. Fusarium species isolated from peat soil of Pondok Tanjung and Sungai Beriah, Perak. Malays. J. Microbiol. 2010, 6, 102-105. [CrossRef]

5. Mandeel, Q.A.; Abbas, J.A. Survey of Fusarium species in an arid environment of Bahrain. Mycopathologia 1994, 127, 167-173. [CrossRef]

6. Kommendahl, T.; Abbas, H.K.; Barnes, P.M.; Mirocha, C.J. Prevalance and toxigenicity of Fusarium species form soils of Norway near the Arctic Circle. Mycologia 1988, 80, 790-794. [CrossRef]

7. Ananda, K.; Sridhar, K.R. Diversity of endophytic fungi in the roots of mangrove species on the west coast of India. Can. J. Microbiol. 2002, 48, 871-878. [CrossRef] [PubMed]

8. Hyde, K.D.; Lee, S.Y. Ecology of Mangrove Fungi and Their Role in Mutrient Cycling: What Gaps Occur in Our Knowledge? Hydrobiologia 1995, 295, 107-118. [CrossRef] 
9. Kohlmeyer, J.; Bebout, B.; Vlkmann-Kohlmeyer, B. Decomposition of mangrove wood by marine fungi and teredinids in Belize. Mar. Ecol. 1995, 16, 27-39. [CrossRef]

10. Dittmar, T.; Hertkorn, N.; Kattner, G.; Lara, R.J. Mangroves, a major source of dissolved organic carbon to the oceans. Glob. Biogeochem. Cycles 2006, 20, 1-7. [CrossRef]

11. Kuthubutheen, A.J. Leaf surface fungi associated with Avicennia alba and Rhizophora mucronata in Malaysia. In Proceedings of the Asian Symposium on Mangrove Environment-Research and Management, Kuala Lumpur, Malaysia, 25-29 August 1980.

12. Alias, S.A.; Zainuddin, N.; Jones, E.G. Biodiversity of marine fungi in Malaysian mangroves. Bot. Mar. 2010, 53, 545-554. [CrossRef]

13. Latiffah, Z.; Kok, F.M.; Mei, H.H.; Maziah, Z.; Baharuddin, S. Fusarium species isolated from mangrove soil in Kampung Pantai Acheh, Balik Pulau, Pulau Pinang, Malaysia. Trop. Life Sci. Res. 2010, 21, 21-29. [PubMed]

14. Leslie, J.F.; Summerell, B.A. The Fusarium Laboratory Manual; Wiley-Blackwell: Oxford, UK, 2006.

15. O'Donnell, K.; Kistler, H.C.O.; Cigelnik, E.L.; Ploetz, R.C. Multiple evolutionary origins of the fungus causing Panama disease of banana: Concordant evidence from nuclear and mitochondrial gene genealogies. Proc. Natl. Acad. Sci. USA 1998, 95, $2044-2049$. [CrossRef]

16. O'Donnell, K.; Cigelnik, E. Two divergent intragenomic rDNA ITS2 Types within a monophyletic lineage of the Fungus Fusarium are nonorthologous. Mol. Phylogenet. Evol. 1997, 7, 103-116. [CrossRef] [PubMed]

17. White, T.J.; Bruns, T.; Lee, S.; Taylor, J. Amplification and direct sequencing of fungal ribosomal RNA genes for phylogenetics. In PCR Protocols: A Guide to Methods and Applications; Innis, M., Gelfand, D., Shinsky, J., White, T., Eds.; Academic Press: New York, NY, USA, 1990; pp. 315-322.

18. Tamura, K.; Peterson, N.; Stecher, G.; Nei, M.; Kumar, S. MEGA5: Molecular evolutionary genetics analysis using maximum likelihood, evolutionary distance, and maximum parsimony methods. Mol. Biol. Evol. 2011, 28, 2731-2739. [CrossRef] [PubMed]

19. O'Donnell, K. Molecular phylogeny of the Nectria haematococca-Fusarium solani species complex. Mycologia 2000, 92, 919-938. [CrossRef]

20. Proctor, R.H.; Desjardins, A.E.; Plattner, R.D.; Hohn, T.M. A polyketide synthase gene required for biosynthesis of fumonisin mycotoxins in Gibberella fujikuroi mating population A. Fungal Genet. Biol. 1999, 27, 100-112. [CrossRef]

21. Qi, Y.X.; Zhang, X.; Zhang, H.; Lu, Y.; Yu, Q.; Zhang, H.; Xie, Y. First report of dieback of mango caused by Fusarium decemcellulare in China. J. Phytopathol. 2013, 161, 735-738. [CrossRef]

22. Geiser, D.M.; Ivey, M.L.; Hakiza, G.; Juba, J.H.; Miller, S.A. Gibberella xylarioides anamorph: Fusarium xylarioides), a causative agent of coffee wilt disease in Africa, is a previously unrecognized member of the G. fujikuroi species complex. Mycologia 2005, 97, 191-201. [CrossRef]

23. O'Donnell, K.; Humber, R.A.; Geiser, D.; Kang, S.; Park, B.; Robert, V.A.; Crous, P.W.; Johnston, P.R.; Aoki, T.; Rooney, A.P.; et al. Phylogenetic diversity of insecticolous fusaria inferred from multilocus DNA sequence data and their molecular identification via FUSARIUM-ID and Fusarium MLST. Mycologia 2012, 104, 427-445. [CrossRef]

24. Rowell, D.L. Soil Science: Methods and Applications; Routledge: Harlow, Essex, UK, 1994.

25. Gee, G.W.; Bauder, J.W. Particle-size analysis. Methods Biogeochem. Wetl. 2018, 9, 383-411. [CrossRef]

26. Walkley, A.; Black, I.A. An examination of Degtjareff method for determining soil organic matter, and proposed modification of the chromic acid tritation method. Soil Sci. 1934, 37, 29-38. [CrossRef]

27. Logrieco, A.; Moretti, A.; Ritieni, A.; Bottalico, A.; Corda, P. Occurrence and toxigenicity of Fusarium proliferatum from preharvest maize ear rot, and associated mycotoxins, in Italy. Plant Dis. 1995, 79, 727-731. [CrossRef]

28. Nalim, F.A.; Samuels, G.J.; Wijesundera, R.L.; Geiser, D.M. New species from the Fusarium solani species complex derived from perithecia and soil in the Old World tropics. Mycologia 2011, 103, 1302-1330. [CrossRef]

29. Bogale, M.; Steenkamp, E.; Wingfield, M.; Wingfield, B. Diverse Fusarium solani isolates colonise agricultural environments in Ethiopia. Eur. J. Plant Pathol. 2009, 124, 369-378. [CrossRef]

30. Chehri, K. Molecular phylogeny of the Fusarium solani species complex (FSSC) isolated from soils in Iran. Botany 2014, 92, 815-820. [CrossRef]

31. Nirenberg, H.I.; Brielmaier-Liebetanz, U. Nectria ipomoeae Halst., Anamorph: Fusarium striatum Sherb. an Passiflora edulis Sims. Nachr Dtsch Pflanzenschutzd 1996, 48, 270-274.

32. Rossman, A.Y.; Samuels, G.J.; Rogerson, C.T.; Lowen, R. Genera of Bionectriaceae, Hypocreaceae and Nectriaceae (Hypocreales, Ascomycetes). Stud. Mycol. 1999, 42, 1-248.

33. Burgess, L.W.; Summerell, B.A. Mycogeography of Fusarium: Survey of Fusarium species from subtropical and semiarid grassland soils from Queensland, Australia. Mycol. Res. 1992, 96, 780-784. [CrossRef]

34. Mandeel, Q.A. Biodiversity of the genus Fusarium in saline soil habitats. J. Basic Microbiol. 2006, 46, 480-494. [CrossRef]

35. Nordahliawate, S.; Izzati, N.A.; Azlin, N.; Baharudin, S. Diversity of Fusarium species isolated from soil cultivated with cucurbits within east coast, Peninsular Malaysia. Pertanika J. Trop. Agric. Sci. 2012, 35, 381-386.

36. Gott, K.P.; Burgess, L.W.; Balmas, V.; Duff, J. Mycogeography of Fusarium: Fusarium species in soils from Palm Valley, Central Australia. Australas. Plant Pathol. 1994, 23, 112-117. [CrossRef]

37. Summerell, B.; Rugg, C.; Burgess, L. Mycogeography of Fusarium: Survey of Fusarium species associated with forest and woodland communities in north Queensland, Australia. Mycol. Res. 1993, 97, 1015-1019. [CrossRef] 
38. Summerell, B.A.; Leslie, J.F.; Liew, E.C.Y.; Laurence, M.H.; Bullock, S.; Petrovic, T.; Bentley, A.R.; Howard, C.G.; Peterson, S.A.; Walsh, J.L.; et al. Fusarium species associated with plants in Australia. Fungal Divers. 2011, 46, 1-27. [CrossRef]

39. McMullen, M.P.; Stack, R.W. Effects of isolation techniques and media on the differential isolation of Fusarium species. Phytopathology 1983, 73, 458-462. [CrossRef]

40. Latiffah, Z.; Mohd Zariman, M.; Baharuddin, S. Diversity of Fusarium species in cultivated soils in Penang. Malays. J. Microbiol. 2007, 3, 27-30. [CrossRef]

41. Garibaldi, A.; Gilardi, G.; Gullino, M.L. Seed transmission of Fusarium oxysporum f. sp. lactucae. Phytoparasitica 2004, 32, 61-65. [CrossRef]

42. Xia, J.W.; Sandoval-Denis, M.; Crous, P.W.; Zhang, X.G.; Lombard, L. Numbers to names-restyling the Fusarium incarnatumequiseti species complex. Persoonia 2019, 43, 186-221. [CrossRef] [PubMed]

43. Bushula, V.S. Native Fusarium Species from Indigenous Fynbos Soils of the Western Cape. Master's Thesis, Stellenbosch University, Stellenbosch, South Africa, 2008. Available online: http:/ / hdl.handle.net/10019.1/2437 (accessed on 1 November 2020).

44. Karim, N.F.A.; Mohd, M.; Nor, N.M.I.M.; Zakaria, L. Saprophytic and potentially pathogenic fusarium species from peat soil in Perak and Pahang. Trop. Life Sci. Res. 2016, 27, 1-20. [PubMed]

45. Sarquis, M.M.; Borba, C.M. Fusarium species in sandy soil from Ipanema Beach. J. Basic Microbiol. 1997, 37, 425-429. [CrossRef]

46. Jeschke, N.; Nelson, P.E.; Marasas, W.F.O. Fusarium species isolated from soil samples collected at different altitudes in the Transkei, southern Africa. Mycologia 1990, 82, 727-733. [CrossRef]

47. Onyike, N.B.N.; Nelson, P.E. The distribution of Fusarium species in soils planted to millet and sorghum in Lesotho, Nigeria and Zimbabwe. Mycopathologia 1993, 121, 105-114. [CrossRef]

48. Steiman, R.; Guiraud, P.; Sage, L.; Seigle-Murandi, F. Soil mycoflora from the Dead Sea Oases of Ein Gedi and Einot Zuqim (Israel). Antonie Leeuwenhoek 1997, 72, 261-270. [CrossRef]

49. Chehri, K. First report of three new Fusarium species isolated from garden soil in southern Iran. Rostaniha 2015, $16,81-87$.

50. Kara, Ö.; Bolat, I. Influence of soil compaction on microfungal community structure in two soil types in Bartin Province, Turkey. J. Basic Microbiol. 2007, 47, 394-399. [CrossRef]

51. Panda, T.; Panda, B.; Prasad, B.; Mishra, N. Influence of soil environment and surface vegetation on soil micro flora in a coastal Sandy Belt of Orissa, India. J. Hum. Ecol. 2009, 27, 69-73. [CrossRef]

52. Hoorman, J.J.; Islam, R. Understanding Soils Microbes and Nutrient Recycling; Agriculture and Natural Resources, Ohio State University Extension: Columbus, OH, USA, 2010; Available online: http:/ / ohioline.osu.edu/factsheet/SAG-16 (accessed on 1 November 2020).

53. Swer, H.; Dkhar, M.S.; Kayang, H. Fungal population and diversity in organically amended agricultural soils of Meghalaya, India. J. Org. Syst. 2011, 6, 3-12.

54. Fargasova, A. The influence of various nitrogen-sources on the growth, conidiation and pigment production of the brown mutant Trichoderma-VIRIDE M-108. Biologia 1992, 47, 453-464.

55. Joshi, I.J.; Chauhan, R.K.S. Distribution of soil microfungi in various soil types of Chambal Ravines. Proc. Indian Natl. Sci. Acad. 1982, 48, 525-533.

56. Rousk, J.; Brookes, P.; Bååth, E. Contrasting soil pH effects on fungal and growth suggest functional redundancy in carbon mineralization. Appl. Environ. Microbiol. 2009, 75, 1589-1596. [CrossRef] [PubMed]

57. Gonzalez-Acosta, B.; Bashan, Y.; Hernandez-Saavedra, N.Y.; Ascencio, F.; De La Cruz-Agüero, G. Seasonal seawater temperature as the major determinant for populations of culturable bacteria in the sediments of an intact mangrove in an arid region. FEMS Microbiol. Ecol. 2006, 55, 311-321. [CrossRef]

58. Thatoi, H.N.; Behera, B.C.; Dangar, T.K.; Mishra, R.R. Microbial biodiversity in mangrove soils of Bhitarkanika, Odisha, India. Int. J. Environ. Biol. 2012, 2, 50-58.

59. Wheeler, K.A.; Hurdman, B.F.; Pitt, J. Influence of $\mathrm{pH}$ on the growth of some toxigenic species of Aspergillus, Penicillium and Fusarium. Int. J. Food Microbiol. 1991, 12, 141-149. [CrossRef]

60. Nevarez, L.; Vasseur, V.; Le Madec, A.; Le Bras, M.; Coroller, L.; Leguérinel, I.; Barbier, G. Physiological traits of Penicillium glabrum strain LCP 08.5568, a filamentous fungus isolated from bottled aromatised mineral water. Int. J. Food Microbiol. 2009, 130, 166-171. [CrossRef]

61. Nazim, K.; Ahmed, M.; Shaukat, S.S.; Khan, M.U.; Rao, T.A.; Ali, Q.M.; Sherwani, S.K. Distribution and diversity of airborne microflora under mangrove forest at Sandspit Area Karachi, Pakistan. Sci. Technol. Dev. 2012, 31, 305-311.

62. Maina, P.; Okoth, S.; Monda, E. Impact of land use on distribution and diversity of Fusarium spp. in Taita Taveta, Kenya. Trop. Subtrop. Agroecosyst. 2009, 11, 323-335.

63. Banakar, S.P.; Thippeswamy, B.; Thirumalesh, B.V.; Naveenkumar, K.J. Diversity of soil fungi in dry deciduous forest of Bhadra Wildlife sanctuary, western Ghats of southern India. J. For. Res. 2012, 23, 631-640. [CrossRef]

64. Oritsejafor, J. Influence of moisture and $\mathrm{pH}$ on growth and survival of Fusarium oxysporum f.sp. elaeidis in soil. Trans. Br. Mycol. Soc. 1986, 87, 511-517. [CrossRef]

65. Gauthier, G.M.; Keller, N.P. Crossover fungal pathogens: The biology and pathogenesis of fungi capable of crossing kingdoms to infect plants and humans. Fungal Genet. Biol. 2013, 61, 146-157. [CrossRef] [PubMed]

66. Nucci, M.; Anaissie, E. Fusarium infections in immunocompromised patients. Clin. Microbiol. Rev. 2007, 20, 695-704. [CrossRef] 
67. O’Donnell, K.; Sutton, D.A.; Rinaldi, M.G.; Gueidan, C.; Crous, P.W.; Geiser, D.M. Novel multilocus sequence typing scheme reveals high genetic diversity of human pathogenic members of the Fusarium incarnatum-F. equiseti and F. chlamydosporum species complexes within the United States. J. Clin. Microbiol. 2009, 47, 3851-3861. [CrossRef] [PubMed]

68. Backhouse, D.; Burgess, L.W. Mycogegraphy of Fusarium climatic: Analysis of the distribution within Australia of Fusarium species in section Gibbosum. Mycol. Res. 1995, 99, 1218-1224. [CrossRef]

69. Smith, S.N. An overview of ecological and habitat aspects in the genus Fusarium with special emphasis on the soil-borne pathogenic forms. Plant Pathol. Bull. 2007, 16, 97-120. 